\title{
EL PAÍS DE LA CANELA: \\ A PRÁTICA TRADUTÓRIA NA RELEITURA DA HISTÓRIA
}

\author{
EL PAÍS DE LA CANELA: \\ THE TRANSLATION PRACTICE IN THE REREADING OF HISTORY
}

\author{
Gracielle Marques ${ }^{1}$ \\ Andréa Moraes da Costa ${ }^{2}$ \\ Allan Adrian Silva Gomes ${ }^{3}$
}

\begin{abstract}
Resumo: Este trabalho objetiva analisar a releitura realizada pelo romance El país de la canela (2008), de William Ospina, do relato de viagem de Frei Gaspar de Carvajal sob a premissa do romance histórico contemporâneo de mediação (FLECK, 2017) e dos Estudos da Tradução. A análise se fixa no contradiscurso do narrador "ex-cêntrico" e sua prática tradutória cultural, os quais desvelam as falsificações do olhar estrangeiro e se mostram uma via deslegitimadora de práticas colonizadoras. Mediante a prática tradutória cultural, Ospina questiona as estratégias representacionais que reforçaram o triunfo dos colonizadores sobre os nativos a partir de novas perspectivas.
\end{abstract}

Palavras-chave: Amazônia; descolonização; tradução; literatura colombiana; literatura e história.

\begin{abstract}
This paper aims to analyze the rereading performed of the novel El País de la Canela (2008), written by William Ospina, in the travelling writing of Frei Gaspar de Carvajal under the premise of the contemporary historical novel of mediation (FLECK, 2017) and Translation Studies. The analysis of this paper focuses on the counter-discourse of the "ex-centric" narrator and his cultural translation practice, which unveils the falsifications of the foreign gaze and shows a delegitimizing way of colonizing practices. Through cultural translation practice Ospina questions the representational strategies that reinforced the triumph of the colonizers over the natives from new perspectives.
\end{abstract}

Keywords: Amazon; decolonization; Colombian literature; literature and history; translation.

\section{Introdução}

\footnotetext{
${ }^{1}$ Doutora em Letras pela UNESP FCL/Assis. Professora Adjunta na Universidade Federal de Rondônia: no curso de Letras Espanhol, literatura e língua espanhola, e no Programa de Mestrado Acadêmico em Letras, na Área de Estudos Literários (PPGMEL), literatura comparada. E-mail: gracielle.marques@unir.br

${ }^{2}$ Doutora em Letras - Teoria da Literatura - pela UNESP/São José do Rio Preto/SP. Professora da Universidade Federal de Rondônia/UNIR- Porto Velho (RO)/Brasil: atua no curso de Letras Inglês e no Programa de Mestrado Acadêmico em Letras, na Área de Estudos Literários (PPGMEL). Coordena o Programa de Extensão "Livros que me Encantam". Líder do Grupo de Pesquisa "Estudos da Tradução da Amazônia" - GETRA. E-mail: mcostandrea@gmail.com

3 Graduando em Letras-Espanhol/Literaturas pela Universidade Federal de Rondônia (UNIR), participou do Programa de Monitoria Acadêmica e dos projetos PIBID e PIBIC (2018/2019). É membro do grupo de pesquisa "Literatura, educação e cultura: caminhos da alteridade". E-mail: allanadrian28@gmail.com
} 
El País de la Canela (2008), do poeta, ensaísta e romancista colombiano William Ospina (1954-), compõe uma trilogia que ficcionaliza as descomunais expedições pelo espaço amazônico durante o século XVI realizadas em nome do Império espanhol, movidas incialmente pela busca do País da canela e depois pelas riquezas do fabuloso país de Omagua, o reino das amazonas, onde se acreditava que havia os incalculáveis tesouros da cidade do El Dorado. O romance foi galardoado com o Premio Internacional de Novela Rómulo Gallegos (2009) e, recentemente, foi traduzido para o português por Eric Nepomuceno (2017), proporcionando o encontro dessa obra com outros leitores interessados, por exemplo, nas narrativas de cunho histórico sobre a geocultura amazônica.

A trilogia é narrada por um personagem ficcional, Cristóbal, que teria participado como soldado nas expedições e que, portanto, conta sua versão da viagem que percorreu o rio Amazonas em toda sua extensão pela expedição de Francisco Orellana. Os oito meses e 6.000 km de navegação, em 1541, ficaram registrados no famoso Relatório do novo descobrimento do famoso rio grande descoberto pelo capitão Francisco de Orellana (1541), de Frei dominicano Gaspar de Carvajal (1504-1584), considerado um dos primeiros relatos de viagem sobre a penetração do europeu no espaço amazônico ${ }^{4}$.

Na ordem cronológica das publicações, em Ursúa (2005) narra-se o ambiente explosivo acumulado pelas expectativas de poder frustradas, no Vice-Reino do Peru, assim como o desejo despertado em Pedro de Ursúa pela riqueza do El Dorado buscado na selva amazônica. O segundo romance, El país de la canela, relata a expedição comandada por Gonzalo Pizarro, em 1541, e a acidental navegação pelo rio das amazonas, protagonizada por Francisco de Orellana. No último romance, La serpiente sin ojos (2012), o relato se inicia com as circunstâncias prévias a segunda expedição (1560) organizada por Pedro de Ursúa, que contou com a participação de sua esposa, Inés de Atienza, a mestiça indo-hispânica. Essa presença feminina e a crescente insatisfação dos soldados se relacionam com a traição e rebelião comandada por Lope de Aguirre e seus homens, os marañones, contra Ursúa e o rei espanhol Felipe II, em 1561.

Como é sabido, na literatura hispano-americana um dos gêneros que se destacou na nas últimas décadas foi o romance histórico. É evidente que esse tipo de gênero não está restrito ao universo hispano-americano, mas é verdade também que as obras produzidas nesse contexto

\footnotetext{
${ }^{4}$ Conforme esclarece Antonio Porro (2016, p.29-31), em 1538, Diego Nunes, um soldado mestiço indo-português, nascido no Brasil, participou da malograda expedição de Alonso Mercadillo, enviada por Francisco Pizarro, que chegou próximo à região situada entre Tefé e Coari (Alto Amazonas). Essa viagem resultou na primeira crônica sobre a Amazônia brasileira, enviado ao rei João III, no qual Nunes descrevia aspectos da terra e dos indígenas, além de se oferecer para conquistá-la.
} 
cultural chamam a atenção por suas particularidades, quantidade e qualidade. Em âmbito geral, podemos perceber que desde seu surgimento, no início do século XIX, o romance histórico vem sendo recebido com êxito junto ao público leitor e também vem apresentando boa aceitação pela crítica especializada, que acompanhou as alterações ocorridas, ao longo do tempo, com relação a algumas de suas características.

A ficcionalização sobre a conquista da Amazônia pelos espanhóis, especialmente em torno da polémica figura de Lope de Aguirre, deu origem a um ciclo literário de romances históricos no qual figuram títulos como o dos espanhóis Ciro Bayo, Los Marañones (Leyenda áurea del nuevo mundo) (1913), e Ramón J. Sénder, La aventura equinoccial de Lope de Aguirre (1947) - que inspirou o filme Aguirre, la cólera de Dios (1972), dirigido por Werner Herzog -; o dos venezuelanos Arturo Uslar Pietri, El camino del Dorado (1947) e Miguel Otero Silva, Lope de Aguirre, príncipe de la libertad (1979) e o do argentino Abel Posse, Daimon (1978).

Assim, o principal objetivo deste trabalho é demonstrar a releitura ficcional operada em El País de la Canela às fontes históricas, sobretudo o Relatório, de Carvajal. Dessa forma, a análise aborda as implicações do ponto de vista do narrador "ex-cêntrico" e sua prática tradutória intercultural. Além disso, analisamos excertos que tratam da sobreposição de sentidos novos e antitéticos produzidos pelo discurso literário com o fim de alcançar uma via deslegitimadora das práticas colonizadoras.

A hipótese deste trabalho é que o romance em questão atende aos requisitos da modalidade romance histórico de mediação (FLECK, 2017) e permite reflexões acerca da atividade tradutória, suscitando ainda reflexões sobre questões de representação históricas, a relação entre cultura e império, gênero, a alteridade e a identidade cultural, temas relevantes no contexto do romance histórico e que podem ser lidos de maneira interdisciplinar.

Para tanto, nos apoiamos em estudos teórico-críticos sobre o relato de viagem de Carvajal, como o de Beatriz Pastor (1983) e Antonio Porro (2007; 2016). Sobre o pensamento descolonial. E quanto aos Estudos da tradução usamos as referências de autores como Edwin Gentzler (2009) e Aníbal Quijano (2005), entre outros. Com relação à questão do gênero híbrido de história e ficção na contemporaneidade, contamos com o respaldo teórico de Linda Hutcheon (1991) e Francisco Gilmei Fleck (2017).

Estudos com foco na produção literária do sistema letrado escrita por escritores de dentro ou de fora da região, que problematizam as questões mencionadas, são de suma importância para contribuir com as (re)leituras das representações histórico-literárias do espaço 
amazônico, não apenas no sentido de ampliar o conhecimento das produções e questionamentos contemporâneos sobre a região, mas também pelo fato da escrita híbrida de história e ficção atual mostrar-se como um corpus importante para a formação de leitores críticos, devido as suas características narrativas.

\section{0 romance histórico de mediação: via crítica e criativa no diálogo com a história}

Entre os aspectos que podemos destacar sobre a construção romanesca presentes em $E l$ país de la canela está a organização linear da diegese, seguida de um fluxo narrativo cronológico. Além da utilização de uma linguagem acessível, outra característica definidora dessa escrita híbrida é a de ser uma releitura crítica verossímil do passado. Esses elementos escriturais que revestem o material histórico são característicos da modalidade atual (a partir de 1980) do romance histórico, evidenciado pelo estudioso Gilmei Francisco Fleck (2017) que cunhou essa fase de "Romance histórico contemporâneo de Mediação", a qual comprova a renovação e vigência do gênero.

Dessa forma, o romance adota uma estrutura linear que enlaça diversos fios narrativos e avança seguindo o curso cronológico da história. Cristóbal narra para um interlocutor a sua vida e, especialmente, o episódio da travessia pelo espaço amazônico na condição de soldado da expedição de Gonzalo Pizarro e Francisco Orellana.

$\mathrm{O}$ relato pode ser dividido em quatro momentos. No primeiro, relata-se a infância de Cristóbal, transcorrida na ilha La Espanhola (atual Haiti e República Dominicana), aos cuidados de uma criada indígena, Amaney, que ele só compreendeu tratar-se de sua legítima mãe no regresso da Europa, quando esta já havia falecido. O personagem passa sua juventude longe do pai, um espanhol que imigrou para o Peru e integrou o grupo do conquistador espanhol Francisco Pizarro. Nesse ínterim, o pai falece e o jovem viaja até o Peru para reclamar seus direitos nas possessões que lhe caberia como herdeiro. O narrador reflete criticamente sobre a fundação de Lima e o domínio de Cuzco, pelos conquistadores, e denúncia a violência contra os Incas e outras populações indígenas, motivada pela ambição dos irmãos Pizarro. Depois de não conseguir sua herança, o personagem conhece Gonzalo Pizarro, que está agenciando homens para uma nova expedição. Sem ter outra opção, embarca em direção ao País da canela.

No segundo momento, que ocupa a maior parte do romance, o narrador relata a expedição ao país da canela e a acidental viagem pelo rio das Amazonas, marcada pela fome e ameaça constante de ataques indígenas. 
No terceiro momento, ocorrido depois do fim da travessia e o retorno ao Caribe, Cristóbal narra sua viagem a Europa, em uma nítida estratégia de revisão da ação e do olhar colonizador. Seu olhar periférico e fronteiriço passa a traduzir ambos os lados do mundo de forma plural, sem medo da diversidade e das contradições. Esse percurso foi motivado pela missão ficcional, que lhe foi incumbida no início de 1543. Sua missão compreendia levar a carta com as notícias da nova região, escrita por Gonzalo Fernández de Oviedo ${ }^{5}$ - cronista de Índias, prefeito e governador de Santo Domingo, nomeado por Carlos V em 1532 - a Pietro Bembo, cardeal e secretário pessoal do papa Paulo III. Nessa etapa, o narrador fica conhecido como o "contador de histórias" e o sobrevivente da viagem pelo rio das Amazonas.

No quarto momento, o da enunciação, Cristóbal, já adulto, encontra-se no Panamá, narrando sua história pessoal e a da expedição que cruzou a Cordilheira dos Andes em busca das selvas da bacia amazônica, onde supostamente continha a floresta de canela. Ao final da narrativa, descobrimos que seu interlocutor é ninguém menos que Pedro de Ursúa. Toda a narrativa se configura como uma tentativa de dissuadir ou alertar Ursúa sobre o retorno à região para um novo empreendimento em busca do El Dorado.

Ambos os momentos narrativos mencionados estão conectados pela história pessoal do personagem, que envolve a passagem da juventude à vida adulta e a reflexão sobre sua identidade cultural mestiça. Entendemos que o conceito de mestiçagem é complexo e pode ser entendido, tanto como artimanha discursiva para negar a legitimidade das populações colonizadas, quanto como exercício de impureza, compreendido como resistência às forças de controle que pretendem estabilizar e homogeneizar as diferenças, conforme preconiza María Lugones (1999). É nessa segunda acepção, próxima do sentido de entre-lugar discursivo, que o romance adquire caráter autorreflexivo e crítico.

Outro ponto de destaque da narrativa é a linguagem clara e fluida ao longo dos trinta e três capítulos, tingida, em muitos momentos, de um especial lirismo. Esse aspecto se intensifica no romance La serpiente sin ojos (2012), que oferece ao final de cada capítulo um poema, expressando uma rede infinita de outros saberes em oposição à percepção cartesiana. Nesse texto, de composição híbrida, instaura-se uma zona criativa que se configura como o espaço do Outro, feito das confrontações e resistência à ordem dominante. A linguagem acessível,

\footnotetext{
${ }^{5}$ A carta de Oviedo a Bembo datado em Santo Domingo, em 20 de janeiro de 1543, contém vários pontos de interesse, entre eles: a história da navegação de Orellana; a paisagem extraordinária, a magnitude do rio e o encontro com as Amazonas e a existência do rei Dorado. Essas informações seriam publicadas posteriormente em sua História General y Natural de las Índias, Islas y Tierra Firme del Mar Océano (CRO, 1986, p.420).
} 
característica dessa modalidade, reforça sua capacidade de abarcar um público amplo, segundo a proposta de Fleck (2017).

Em El país de la canela, o questionamento crítico da história é alcançado, sobretudo, pela focalização narrativa. Conforme mencionamos anteriormente, o romance é narrado por Cristóbal, criação ficcional baseada nos dados históricos de um provável soldado filho de um espanhol e uma indígena, que teria participado da expedição capitaneada por Gonzalo Pizarro e Francisco de Orellana ao mítico País da Canela, em 1541. Dessa forma, o romance de Ospina propõe ao leitor uma nova versão à história narrada no Relatório, de Frei Gaspar de Carvajal.

Isso é realizado por meio desse narrador "ex-cêntrico" que joga com a focalização homodiegética e extradiegética. Essa estratégia cria a possibilidade do narrador acompanhar os fatos cronológicos apresentados no Relatório e também distanciar-se dos fatos narrados por Carvajal, para apresentar comentários que denunciam as atrocidades cometidas em nome da empresa colonial. Também evidencia o caráter polifônico e dialógico dos discursos da conquista, inclusive na época em que foram produzidos. A polifonia refere-se à presença de vozes que, inseridas num texto, tem o poder de tensionar a hegemonia monológica, por meio, muitas vezes, de um discurso contraditório.

Essa dualidade também é característica das releituras críticas do passado na modalidade da metaficção historiográfica, estudada por Linda Hutcheon (1991), da qual se nutre o romance de mediação (FLECK, 2017). Para a estudiosa canadense, os personagens ex-cêntricos, marginalizados e periféricos da historiografia dominante, que povoam essas narrativas, assumem um posição paradoxal, pois o ex-cêntrico é aquele que está fora do centro, isto é, aquele que "inevitavelmente [está] identificado com o centro ao qual aspira, mas que lhe é negado" (HUTCHEON, 1991, p.88).

Essa situação é exemplar em El país de la canela, pois o narrador se posiciona na fronteira cultural, da qual lança um olhar dialético sobre ambos os mundos herdados de um lado e outro do Atlântico. Com isso, o discurso ficcional através da eleição do foco narrativo em primeira pessoa ancorasse na perspectiva dos excluídos da chamada historiografia das Índias, emissora das "verdades" históricas, contudo tensiona a todo o momento a dicotomia centro versus periferia. Essa é outra singularidade do romance histórico de mediação e um recurso predominante no romance de Ospina.

Diante do exposto, veremos que o processo de questionamento da visão eurocêntrica operado pelo narrador se dá por distintas vias: ao reapresentar os fatos tomando sua experiência pessoal mestiça e denunciar as crueldades da expedição megalômana de Gonzalo Pizarro e, 
sobretudo, ao se colocar no papel de tradutor cultural, realizando o intercâmbio cultural, em virtude do qual estabelece um discurso que participa de outras perspectivas existenciais.

\section{Escrita e tradução: o olhar descolonial}

Através da produção do romance histórico contemporâneo de mediação, observamos a reinterpretação e desvelamento de circunstâncias obscuras dos acontecimentos históricos, sobretudo os que tomam como eixo central as estratégias coloniais presentes nas crônicas de "descobrimento" e conquista de distintas regiões da América Latina. Por esse viés, conforme aponta Amalia Pulgarín (1995, p.57, tradução nossa), "o romance [histórico] assume o papel de revelador da história utilizando para isso um discurso desmistificador e paródico com o qual não pretende em nenhum momento resolver enigmas, senão questioná-los a partir de uma ótica diferente".

Essa ótica diferente criada pelo escritor latino-americano está articulada com a memória e a história política do continente. Dessa forma, entendemos que o romance de Ospina assume o gesto descolonial para reinterpretar um fato histórico que está na origem da dependência econômica e do constante encobrimento da realidade amazônica pelo olhar Europeu.

Conforme preconizou o sociólogo peruano Aníbal Quijano em 1989, o processo histórico da colonização na América Latina constitui um novo padrão de poder mundial: a colonialidade do poder. Esse novo padrão estabeleceu as diferenças entre conquistadores e conquistados por meio da ideia de raça, baseada na inferioridade de uns em relação a outros e na pretenciosa universalidade de uma etnia, a branca, em particular. Também se impôs pela "articulação de todas as formas históricas de controle do trabalho, de seus recursos e de seus produtos, em torno do capital e do mercado mundial" (QUIJANO, 2005, p. 117), ou seja, se baseou na diferenciação de formas de controle não remuneradas, associadas às populações colonizadas, e na ideia do privilégio do pagamento do trabalho para os brancos.

Para Walter Mignolo (2010, p.12), a colonialidade do poder (econômico e político) se apoiou em outras formas de controle, como a do conhecer (epistemologia), do entender ou compreender (hermenêutica), do sentir (aesthesis) e do ser (gênero e sexualidade). Na leitura que Mignolo (2010, p.14, tradução nossa) faz da contribuição do pensamento de Quijano ele afirma que: "O conceito de colonialidade abriu a reconstrução e restituição de histórias silenciadas, subjetividades reprimidas, linguagens e conhecimentos subalternizados pela ideia de Totalidade definida sob o nome de modernidade e racionalidade". 
Ao tomar partido da crítica descolonial, Gilmei Francisco Fleck (2017, p.127-128) assevera que no contexto latino-americano, a escrita assume o gesto descolonial quando o escritor comprometido com sua realidade se vale das mesmas ferramentas da subjugação colonial para produzir o efeito contrário. Se o poder exercido pela colonialidade/modernidade nas primeiras ações colonizadoras utilizou a língua escrita como um poderoso mecanismo para suplantar a cultura oral nativa, no romance histórico crítico a escrita letrada atua em sentido contrário, isto é, aponta para as estratégias dominantes em prol da descolonização dos saberes.

Diante disso, se faz operativo analisar a perspectiva descolonizadora assumida pelo projeto estético e ideológico de William Ospina, uma vez que através do tratamento literário dado aos fatos históricos e os recursos narrativas utilizados, a situação colonial, ainda vigente, é questionada. Essa mudança é possível graças à percepção participativa que torna visível a presença de outros pontos de vista, isto é, de outras existências por meio da tarefa tradutória do narrador.

Se pensarmos, de maneira geral, a ação de tradutores a serviço dos europeus, o que permitiu o acesso às informações necessária do "Novo Mundo" e a elaboração de estratégias de dominação (FLECK, 2017, p.120-121), é possível considerarmos que na atualidade os Estudos da tradução auxiliam na revisão esse papel. A existência do discurso do colonizador, vista pelo viés descolonial, no contexto amazônico, evidência a necessidade de negociação entre línguas, pois a tradução atua como um recurso que desvela olhares que manipularam de maneira eficiente a história da região. Trata-se de uma tarefa a qual podemos pensar em articulação com o que Edwin Gentzler (2009, p.240) considera sobre essa tarefa no âmbito dos Estudos de Gênero no Quebec: “amplia os espaços semânticos mudos partilhados por outros cujas vozes têm sido abafadas pelas condições linguísticas/discursivas/culturais dominantes de uma sociedade". Visto dessa forma, o sujeito tradutor cultural entra em perspectiva com outros modos de existência e não apenas observa de fora um mundo estendido diante de si, para relacionarmos com as formulações de David Lapoujade (2017, p.47).

Isso nos leva a observar que essa forma de percepção participativa esteve e ainda está longe de presidir os discursos produzidos, especialmente, fora da Região Amazônica. Esta ainda é alvo de especulações e estereótipos produzidos por políticos, cientistas, biólogos, pesquisadores e repórteres que transitam seu espaço na intenção de "re-apresentar a 'realidade' e o próprio Outro [...] tendo como lente de comparação o seu mundo de origem", como apontado por Hélio Rocha (2012, p.17). A posição de quem olha e enuncia é o ponto central na tradução 
e na releitura crítica do discurso historiográfico, conforme já destacamos. Portanto, interessanos analisar como essa perspectiva se configura em El país de la canela.

Desse modo, na próxima seção, focalizaremos a ação tradutória dos personagens históricos Francisco de Orellana e Frei Gaspar de Carvajal. Ambas as construções das personagens no romance são concebidas através de um distanciamento crítico em confronto com o modelo épico, cuja formulação típica é a estabelecida pelas Cartas de relação de Hernán Cortés a Carlos V, segundo a análise de Beatriz Pastor (2008, p. 329).

\section{A (re)visão da tarefa tradutória de Carvajal e Orellana}

O romance El país de la canela se dedica a desconstruir os signos do exótico e do maravilhoso presentes na crônica de Frei Gaspar de Carvajal (1542) a partir de uma situação de enunciação, que aponta a diferença entre o que e quem enuncia a partir da colonialidade e a versão de quem a faz pela visão descolonial. Vale a pena lembrar que esse não é o único intertexto do romance, que dialoga com outras fontes históricas da época.

A inexistência das imaginadas florestas de canela, a experiência da deriva em um ambiente tão adverso, marcado pela fome, faz o discurso narrativo da conquista redefinir o objeto mítico, os objetivos e as funções da expedição. Beatriz Pastor (2008, p.329, tradução nossa) assinala que "[...] o discurso narrativo do fracasso supunha uma simples aceitação da existência de uma realidade diferente da prevista, e apresentava um processo de humanização do conquistador através de sua adaptação a essa nova realidade”.

Por esse prisma, Orellana e seus companheiros de expedição deixam de ocupar o patamar de heróis invencíveis, para se auto representam como homens duramente provados, em uma árdua luta tão somente pela sobrevivência, conforme se lê no Relatório de Carvajal. Essa condição, no entanto, não impediu que esses homens redefinissem seus objetivos míticos (o país da Canela) e lançassem hipóteses sobre a existência do reino do El Dorado. Se por um lado, como sabemos, o relato da descoberta estava dirigido ao imperador Carlos V e visava defender a inocência de Orellana - acusado de traição por Gonzalo Pizarro -, por outro, busca impactar seu destinatário real ao dar notícias sobre a suposta localização da cidade do El Dorado.

Com isso, a realidade vivida pelas sociedades indígenas, que de acordo com o cronista estavam organizadas em chefaturas e senhorios, algumas por até quatrocentos quilômetros ao longo do rio, vai dando lugar a ficcionalização, isto é, se converte em imagens projetadas de 
um mundo fantasiado, no qual os indígenas, quando não são considerados servos do rei são vorazes inimigos que protegem as cobiçadas riquezas imaginárias.

No primeiro caso, quando os espanhóis eram recebidos passivamente, uma das primeiras façanhas era que ao se aproximarem do chefe local, ganhavam sua confiança e, logo após, tratavam de "impor" sua religião aos nativos, através de uma missa celebrada por um missionário. A fé e a espada conformavam a imagem do soldado cristão, rematada ao longo da Idade Média, que então se aventurava na América, conforme lemos:

\footnotetext{
Havia decidido levar um registro dos acontecimentos, e embora sempre tivesse nos lábios sermões e orações, tampouco deixava desamparada a espada. Poucos tripulantes sabiam escrever, e nenhum tinha mais méritos para ser o cronista da viagem que aquele sacerdote, chegado ao Peru com os primeiros conquistadores no ano 33, trazido pelo próprio Vicente de Valverde, o capuchinho que mostrou a Bíblia a Atahualpa e que depois exigiu de Pizarro que crivasse o cortejo, porque o rei tinha jogado o livro no chão (OSPINA, 2017, p. 150).
}

No excerto, observamos a "superioridade" de Frei Gaspar sobre os demais e sua relação com o também frade dominicano Vicente Valverde (1498-1541). A referência ao episódio protagonizado por ele e Atahualpa é um reforço para o leitor entender a relação entre as ações colonizadoras da Igreja e do Estado que soterrou a cosmogonia indígena.

Outro momento de questionamento das estratégias discursivas de colonização do saber cosmogônico se dá, no romance, nas terras de Aparia (Omagua), localizada geograficamente na região do Alto Amazonas, conforme explica Antonio Porro (2007, p.76). Nessa localidade, o Orellana ficcional fez os seus soldados encontrarem grandes vigas de madeira para erguer uma cruz e se põe a explicar aos nativos o significado do símbolo sagrado da religião única, argumentando que nela havia sido cravado o Deus verdadeiro. O romance ironiza a visão cristã apresentada por Orellana ao nos revelar, por meio do narrador, a perspectiva dos nativos. Eles consideraram interessante a cosmovisão do conquistador, pois nela a cruz (madeira, árvore) era mais poderosa que o homem. A negociação de sentidos é alcançada graças à ficção que coloca em tensão a universalidade defendida pelos espanhóis de sua religião.

Juntamente com a missa, efetuava-se o ritual de tomada de posse das terras em nome do rei - não somente nessa localidade, mas em qualquer território pelo qual passavam - a por meio de uma cerimônia simbólica, realizada desde o desembarque de Cristóbal Colón. Nesses momentos, a aproximação e as averiguações de Orellana sobre as riquezas da selva ganham destaque na crônica de Carvajal. Contudo, as condições materiais em que se encontravam lhes permitia apenas ver e questionar alguns nativos. Uma ação realizada com olhos imperiais que veem e possuem, conforme teoriza Mary Louise Pratt (1999, p.33). 
No romance de Ospina, o contato com os indígenas é realizado por Orellana através do acionamento de seu "conhecimento" das línguas indígenas, ou fingimento do saber, uma vez que, como veremos, ao apresentar o discurso na língua alvo, sua língua materna, manipula o novo enunciado para atender aos interesses coloniais. Ao passo que interpretava, isto é, apreendia os enunciados linguísticos auditivos nativos de forma direta ou por meio de outro intérprete nativo, Orellana fazia anotações por escrito. Esse registro é ironizado pelo narrador, pois, segundo ele, ninguém compreendia sua grafia, nem mesmo Frei Carvajal, que também transpunha suas experiências em um caderno.

O motivo da incompreensão, segundo o narrador, se devia ao fato de que o desenho das palavras: "Pareciam partituras de cantos de pássaros e de uivos de macacos, Orellana punha as letras da Espanha a zumbar e a ondular, e chegou a nos dizer que para os índios havia palavras que eram asas e palavras que eram ninhos" (OSPINA, 2017, p. 168). Desse modo, o romance sinaliza para uma prática tradutória/interpretativa ambígua que ora se baseia nas generalizações e nas manipulações, que reforçavam a esperança dos tripulantes sobre os tesouros cobiçados, ora tergiversa e se baseia na transcriação, isto é, na imitação do padrão sonoro e visual da língua fonte, o que ocasionaria a apreensão de outras dimensões contextuais e culturais por parte do tradutor. No entanto, essa tradução não teria chegado até nós na íntegra, pois um dos dramas da viagem foi, justamente, a perda do seu "humilde grafite", o que o obrigou a gravar as informações apenas na memória.

Ainda assim, o que leva o narrador a, de certo modo, colocar as transcrições das informações coletadas dos indígenas cativos por Orellana nesse patamar criativo pode estar relacionado, além do exotismo, com o fato de o romance tentar dar espessura humana aos personagens históricos, descontruindo os contornos fixados pela leyenda negra que difundiu uma imagem do conquistador reduzida ao aspecto sanguinário, traiçoeiro e ambicioso.

Contudo, é a partir dos choques linguísticos e culturais que o soldado mestiço vai desmascarando essas práticas de encobrimento do Outro, da tradução dos conquistadores. Como exemplo, observemos o seguinte excerto do romance:

Estar no reino de Aparia, o maior, não significava mais riquezas nem casas maiores nem tesouros mais visíveis, mas a sensação de haver chegado a um lugar onde pareciam convergir vários mundos. A língua que os índios falavam, e que chamam de omágua, era, segundo eles, a língua que cabe na selva inteira. Orellana, que incansavelmente falava ou fingia falar com eles, disse que aquela língua era compartilhada por irimaes e omáguas, ocamas e cacamillas, yurimaguas e maynas, paguanas e tupinambás (OSPINA, 2017, p.130). 
O narrador ressalta a complexidade da língua indígena (“a língua que cabe na selva inteira”), expressões de um universo multicultural e que, portanto, entendê-la não se restringia ao conhecimento de elementos linguísticos, mas extralinguísticos, já que seus habitantes se encontravam incompreensivelmente entrelaçados a imensidade das praias e ao intricado da selva. O desconhecimento das diferentes variantes linguísticas levou o personagem histórico Orellana a presumir um monolinguismo, ignorando, deste modo, a existência de outros saberes. Ao homogeneizar as línguas na pretensão de eficácia na comunicação com as numerosas populações que margeavam o rio, Orellana nega o ponto de vista dessas sociedades, o que equivale a suas existências. Isso não passa despercebido pela leitura que a ficção realiza das fontes históricas.

Assim, o narrador relembra com ironia que o personagem histórico "tinha apenas um olho, mas parecia ter muitas línguas" (OSPINA, 2017, p.132). A competência de falar com o outro, mas, sobretudo de falar pelo Outro, suplantando-o pela palavra escrita foi uma terrível estratégia de soterramento das culturais orais. Isso leva o romance a deslegitimar essa competência. Em outro momento o narrador relata:

\footnotetext{
Outra vez levamos o índio conosco, e aquela noite suas palavras, ou a nossa interpretação das suas palavras, encheram de magia e de assombro a vigília do barco. E em poucas palavras vou dizer a você o que nos disse o índio naquela noite, ou pelo menos aquilo que o capitão Orellana nos traduziu de tudo que o índio ia contando para ele (OSPINA, 2017, p. 159).
}

Os questionamentos às práticas tradutórias de Orellana pelo narrador também possibilitam que o leitor faça uma reflexão sobre a referida situação. É de se duvidar as ações tradutórias e interpretativas feitas por Francisco de Orellana mesmo com ajuda de outros nativos. Tratava-se de línguas distintas e desconhecidas. Como ele tinha a certeza do que o indígena lhe falava? Que estratégias utilizava para traduzir/interpretar as suas falas? A ficção nos responde: "Orellana dizia que graças à sua paciência tinha ido se familiarizando com as palavras-chave para chegar à informação mais valiosa" (OSPINA 2017, p. 169). Nesse sentido, Orellana fazia uso de certas estratégias da interpretação que consiste, em um primeiro estágio, na retenção da representação mental da mensagem, conceitos e ideias, da mensagem linguística para, em seguida, compreender significados relevantes e encadeá-los com o seu conhecimento de mundo (PAGURA, 2015). O problema é que o seu conhecimento de mundo limitava seu olhar sobre Outro, visto apenas como objeto possuidor de informações valiosas. Diante disso, o narrador volta a introduzir o leitor no terreno da dúvida, usando a estratégia de narrar os bastidores das conversas: 
[...] mas pelo que meu amigo Unuma, a quem Orellana recorria com frequência, ouvir, era pouco o que se conseguia entender da língua do outro. Eu tinha percebido, em diferentes momentos da viagem, quantas tragédias a falta de comunicação pode desencadear, e desde os relatos de Tupinambá aprendi a ouvir com desconfiança a versão de Orellana do que os índios que vieram no barco iam dizendo a ele (OSPINA, 2017, p. 169, 170).

O olhar contestatório instalado na narrativa mira a tradução realizada apenas como produto de uma interpretação motivada pela natureza ideológica da Conquista e promeve a via descolonial, chamando a atenção para os elementos contextuais que envolvem a tradução.

A prática tradutória do conquistador ressaltada pelo narrador ao longo da travessia se configura como uma série de procedimentos que subjugam as palavras e as culturas indígenas ao sistema imperial. Dessa forma, os questionamentos apontam para a maneira como o registro histórico, legitimado pelo poder, constrói “verdades” e sobre a (im)possibilidade de apreensão da realidade, pulverizando as pretensões de transmissão de uma visão de mundo altamente complexa para uma visão reduzida ao código letrado.

Essa orientação se reflete no diálogo que o narrador mantem com seu interlocutor, Pedro de Ursúa, a quem tenta advertir sobre os perigos de uma tradução monológica centrada apenas na visão míope da exploração econômica. Porém, suas conclusões sobre a tarefa tradutória de Orellana se lança sobre a experiência provocada pela inserção em um mundo tão singular que esbarra na impossibilidade dessa ação, conforme lemos:

Quase um mês depois de estar ouvindo suas histórias, convenci-me de que ele estava mentindo, embora visse a mentira como necessária. $\mathrm{O}$ capitão não poderia entender tudo que Wayana ia dizendo a ele. Traduzir de maneira tão fluida e imediata o que um índio diz é impossível sem a ajuda da imaginação (OSPINA, 2017, p.174).

"Traduzir" a realidade desconhecida para a conhecida, feita de um emaranhado multicultural e de geografias diferentes, se torna uma atividade vital para a sobrevivência e o autoconhecimento. Para além da interpretação da realidade, a tarefa tradutória, por vezes, cumpria outro papel na narrativa, segundo Ospina (2017, p.174-175):

Parecia traduzir, mas na verdade recordava e inventava o que todos nós precisávamos ouvir. Qualquer dado solto, qualquer nome, servia para armar um relato que distraísse a tripulação e alimentasse suas esperanças.

Mediante essas explicações sobre a tarefa tradutória, percebemos que o narrador procura desviar a responsabilidade da veracidade das informações para as questões extralinguísticas, nesse caso referentes à cultura receptora e a sua necessidade de ficção e fantasia para a 
sobrevivência. Ele parece concordar com essa necessidade ao mesmo tempo em que aponta para a natureza híbrida de fantasia e realidade dos fatos que presidiram os discursos sobre a região amazônica.

Nisso percebemos seu duplo olhar, típico do ex-cêntrico, que lhe possibilita a participação em dois discursos contraditórios que já não podem ser claramente separados. $\mathrm{O}$ que realmente é válido para a tarefa do tradutor intercultural, deslocado entre uma cultura e outra, como é o caso do soldado que não é mais o que os documentos oficiais disseram sobre a experiência vivida por ele, o que dizem sobre ele, mas o que ele pode afirmar a partir desses dois mundos aos quais pertence.

O romance El país de la canela contorna conscientemente os perigos que essa posição pode enfrentar, isto é, “o perigo de vir a essencializar sua ex-centricidade ou se tornar cúmplice das noções do humanismo liberal sobre universalidade (falar em nome de todos os excêntricos) e eternidade (para sempre)" (HUTCHEON, 1991, p.98). Assim, o narrador-personagem, não pode estabelecer uma ponte entre duas margens estáveis que conectaria o mundo europeu e o indígena, o conhecido e o desconhecido e a selva e a cidade, pois está constituído pelas relações que ambas as margens mantêm entre si.

\section{As amazonas de Frei Carvajal e o ponto de vista do tradutor cultural}

Segundo o viés teórico e interpretativo que estamos seguindo, outro momento chave desse processo de ressignificação do relato de Carvajal se dá com relação à representação das mulheres na história da região.

Em um dos confrontos dos viajantes com os indígenas, entre o rio Trombetas e o Tapajós, os espanhóis são surpreendidos com a participação de mulheres combatendo habilmente com arcos e flechas. Por um lado, frutos de uma sociedade na qual a luta armada era prerrogativa dos homens, uma vez que a atuação das mulheres se limitava ao espaço do lar ou do convento, e por outro, embebidos de tantas histórias fabulosas, os espanhóis não encontram dificuldade em associá-las a seres extraordinários, como as amazonas do reino construído pelas rainhas amazonas Hipólita e Pentesileia nas margens do Mar Negro.

As Amazonas se trasladaram da antiguidade greco-latina direto para as florestas amazônicas na imaginação de muitos viajantes da época, como, por exemplo, na versão de sir Walter Raleigh (1595), que tratou de esticar as histórias que as cercavam até as terras da rainha Elizabeth. O mito conta sobre um reino composto somente por essas mulheres, as quais 
capturavam homens para ter relações sexuais e, posteriormente, as crianças do sexo masculino eram mortas e enviadas ao pai, enquanto as do sexo feminino eram convertidas em guerreiras.

A intertextualidade no romance se manifesta com relação à apresentação feita por Carvajal das mulheres indígenas, vista por ele como amazonas:

Estas mulheres são muito brancas e altas e têm longos cabelos trançados e enrolados na cabeça, são musculosas e andam nuas em pelo, cobrindo sua vergonha com os arcos e as flechas nas mãos lutando como dez índios. Na verdade uma dessas mulheres meteu um palmo de flecha num dos barcos e outra um pouco menos, ficando nossos barcos parecendo porco-espinho (CARVAJAL, 1992, p.79-81).

A força física dessas mulheres se destaca no relato do frade e são retomados pelo narrador homodiegético de El País de la Canela de forma muito semelhante ao relato do frade. Quanto à força e à ferocidade daquelas mulheres ainda ressalta: "Umas delas chegou a atirar uma lança contra o bergantim e para nosso espanto, a lança afundou na madeira do caso, mais de um palmo embora aquela fosse uma das mais duras madeiras da selva". (OSPINA, 2017, p. 156).

O narrador nos deixa claro que não obtiveram muitas informações sobre as Amazonas, apenas algumas noções extraídas de um prisioneiro indígena. Em certo momento da narrativa, diz que seu mestre Gonzalo Fernández de Oviedo já havia lhe falado sobre essas guerreiras em seus estudos, assim como Carvajal (1992, p.87) em seu Relatório afirma que já havia ouvido falar sobre elas a seis léguas de Quito.

No entanto, o narrador, entendido aqui como tradutor cultural, tem a possibilidade de realizar comentários críticos entre o que ficou registrado no Relatório de Carvajal e aquilo que o personagem teria observado da realidade. Com isso, coloca em dúvida a versão de Carvajal, sobre as amazonas e seu reino, apontando a controversa interpretação realizada por Orellana da fala de um indígena cativo e a fantasia dos demais soldados impulsionadas pelas histórias de Frei Gaspar que naquele momento ardia em febre depois de ter recebido uma flechada em um dos olhos, que o deixou com a visão monocular.

$\mathrm{O}$ ponto culminante da perspectiva extradiegética em confronto com o discurso historiográfico se dá quando Cristóbal viaja ao Vaticano para levar a carta de Oviedo e lá, juntamente com Bembo, dão as notícias, a partir de seus pontos de vistas, de suas interpretações, sobre o descobrimento do maior rio do mundo e da selva incomensurável. O narrador tenta explicar em latim detalhes da travessia quando é interrompido pelos cardeais que não se interessam por saber sobre a canela, a organização da expedição ou dos povoados indígenas, porém, tão somente lhes importavam saber sobre as amazonas: si eram feias ou bonitas, sobre 
que tipo de animal cavalgavam, si tinham um ou dois peitos e suas relações com os homens. Desejam comprovar a imagem das guerreiras, formada a partir de suas leituras mitológicas, como se isso fosse possível. Então, ignoram o que o personagem tem a contar para ostentarem o conhecimento erudito sobre o tema em longos debates, isto é, exprimir um ponto de vista externo, que ignora sua perspectiva interna e, portanto, sua existência, conforme argumenta David Lapoujade (2017, p.47).

Esse episódio evidencia a tensão que caracteriza a negociação de sentidos na tradução cultural, predominantemente marcada pela visão assumida pelo tradutor. A percepção dos cardiais não alcança o ponto de vista das mulheres indígenas. Esse modo de conceber o olhar observando de fora o mundo estendido diante de si, ao contrário, do olhar do tradutor cultural que entra no ponto de vista e participa dele é bem recorrente nos discursos da colonialidade do ser (gênero e sexualidade).

Depois de ignorado, Cristóbal retorna ao Caribe e a partir desse lugar, de suas origens maternas, reescreve a interpretação do europeu, tornando visíveis aspectos que não ficaram visíveis nos discursos dominantes. O seguinte excerto funciona como uma nota explicativa, a qual contextualiza os discursos de dominação do corpo feminino, outro aspecto suscitado pela obra analisada e que merece nossa atenção:

O que mais governava aquelas polêmicas era certo ódio pelas mulheres em geral, mas
sobretudo o rechaço frente à ideia de mulheres acostumadas a organizar sua vida sem
homens, entregues sem dúvida a amores entre elas e sem freios diante da luxuria,
dadas as tarefas sujas e cruéis da guerra e capazes de escravizar seus amantes e até
mesmo de matá-los quando as estorvavam. "Se uma coisa está clara" disseram, "é que
a vida pecaminosa daquela nação de fêmeas bárbaras é a pior expressão do paganismo
de que se tenha tido notícia" (OSPINA, 2017, p.207).

O discurso literário lança luz sobre o incomodo ponto de vista das mulheres, traduzidas por selvagens amazonas, por exemplo, capaz de significar o mundo a partir de seus desejos e sua capacidade cognitiva, desempenhando papéis reservados aos homens no mundo ocidental. A forma particular de organização desse Outro é visto como uma ameaça para a ordem patriarcal. O comentário extradiegético do narrador nasce da consciência da opressão que sustenta o funcionamento da ideologia capitalista e patriarcal, fruto da intersecção de práticas discursivas que produzem diferenças étnicas, sociais e sexuais no contexto sociocultural latinoamericana, que marca definitivamente a identidade do narrador.

Longe de uma realidade apenas de papel, o discurso ficcional alcança um grau de criticidade diante da história que graças aos questionamentos da prática tradutória, ação de reescrita e manipulação que tanto pode agir no sentido de encobrir ou desvelar, adquire um 
gesto subversivo que não pretende modificar o passado, mas forjar novas possibilidades para o presente e, especialmente, para o futuro.

\section{Considerações finais}

Em nossa análise procuramos comprovar que o romance usa estratégias escriturais recorrentes no romance histórico contemporâneo de mediação, como a sustentação em dados históricos, organização de forma linear, seguindo o fluxo cronológico da história, focalização centralizada, ora homodiegético ora extradiegético, e ex-cêntrico, além recursos oriundos da novo-romance histórico latino-americano como a intertextualidade e o comentário metaficcional, entre outros, que juntos potencializam o efeito descolonizador da escrita nessa modalidade.

A importância de destacar as características desse gênero literário possibilita o entendimento de que o romance abre um caminho para a crítica ao passado colonial que soterrou a cultura oral indígena, impedindo que suas experiências vividas no momento dos enfrentamentos pudessem transmitir suas línguas, culturas, religiões, economias e formas de organização social, por meio do poder da linguagem literária. Embebido da lógica descolonial, a releitura crítica da historiografia operada pelo romance aposta no desprendimento e na abertura a outras versões, seres e saberes encobertos pela repressão, espoliação e extermínio da racionalidade e modernidade europeia, apelando para a consciência crítica do sujeito mestiço, herdeiro das práticas coloniais.

Assim, todos os recursos formais empregados na narrativa apontam para uma estrutura colonial que ainda persiste. Embora seja impossível modificar o passado, a leitura do romance histórico atual no contexto amazônico permite repensar o presente e forjar um futuro diferente pela aprendizagem crítica que advém de sua leitura.

Como pudemos perceber, o resultado dessa construção literária aponta para o papel da tradução cultural, tomada como o desdobramento ativo da interpretação sobre lugares e espaços instáveis de passagem entre línguas, de travessia de identidades e negociação, de referências culturais que desmascaram as pretensões de superioridade cultural. Assim, o romance abrange grandes áreas para outras análises, tais como: o choque de culturas entre dois mundos totalmente distintos entre colonizador (espanhóis) e o colonizado (indígenas), do qual somos fruto e que nos deixou profundas cicatrizes; a questão da mestiçagem e todos os entrelaçamentos de formas culturais que conservamos na atualidade oriundos da colisão entre forças de convicção simbólica e eficácia militar desigual, entre outros temas que se 
desencadeiam durante a narrativa e que são expostas a questionamentos, não apenas pelo narrador ficcional, mas também pelo leitor.

Concluímos, ainda, que o romance inserido nos parâmetro da mais atual modalidade dos romances históricos se estrutura em uma linguagem mais acessível e menos complexa, contribuindo para a formação de um leitor capaz não apenas de fruir da estética híbrida, mas também de construir criticamente sentidos que o instigue para questões atuais.

\section{Referências}

CARVAJAL, Frei Gaspar de. Relatório do novo descobrimento do famoso rio grande descoberto pelo capitão Francisco de Orellana. Edição bilíngue. Tradução Adja Balbino Durão e Maria Salete Bento Cicaroni. São Paulo: Scritta \& Brasília: Consejería de Educación de la Embajada de España, 1992 (Coleção Orellana, 6).

CRO, Stelio. "Los cronistas primitivos de Indias y la cuestión de antiguos y modernos". Actas del IX Congreso de la Asociación Internacional de Hispanistas (1986), vol.1. España: Vervuert Verlagsgesellschaft, $1989 . \quad$ p. 415-424. $\quad$ Disponível em https://cvc.cervantes.es/literatura/aih/pdf/09/aih_09_1_039.pdf. Acesso: 10 set. 2019

FLECK, Gilmei Francisco. O romance histórico contemporâneo de mediação: entre a tradição e o desconstrucionismo - releituras críticas da história pela ficção. Curitiba: Editora CRV, 2017.

GENTZLER, Edwin. Teorias contemporâneas da tradução. Trad. Marcos Malvezzi. 2. ed. São Paulo: Madras, 2009.

HUTCHEON, L. Poética do pós-modernismo: história, teoria e ficção. Trad. Ricardo Cruz. Rio de Janeiro: Imago, 1991.

LAPOUJADE, David. As existências mínimas. Trad. Hortencia Santos Lencastre. São Paulo: n-1 edições, 2017.

LUGONES, M. Pureza, impureza, separación. In: CARBONELL, N; TORRAS, M. Feminismos literarios. Madrid: Arco Libros, 1999. p. 235- 264.

MIGNOLO, Walter. Desobediencia epistémica: retórica de la modernidad, lógica de la colonialidad y gramática de la descolonialidad. Argentina: Ediciones del signo, 2010.

OSPINA, William. El país de la canela. Buenos Aires: Mondadori, 2013.

La serpiente sin ojos. Buenos Aires: Mondadori, 2013.

. O país da canela. Trad. Eric Nepomuceno. São Paulo: Mundaréu, 2017.

Úrsua. Bogotá: Alfaguara, 2005. 
PAGURA, Reynaldo José. Tradução e interpretação. In: AMORIM, Lauro Maia; RODRIGUES, Cristina C.; STUPIELlO, Érica Nogueira de Andrade (Org.). Tradução e perspectivas teóricas e práticas. São Paulo: Editora Unesp, 2015.

PASTOR, Beatriz. El segundo descubrimiento. La Conquista de América narrada por sus coetáneos (1492-1589). 3. ed. Barcelona: Edhasa, 2008.

PORRO, Antonio. As Crônicas do Rio Amazonas: notas etno-históricas sobre as antigas populações indígenas da Amazônia. 2.ed. Manaus: EDUA, 2016.

Dicionário etno-histórico da Amazônia colonial. São Paulo: IEB-USP, 2007.

PRATT, Mary Louise. Os olhos do império: relatos de viagem e transculturação. Trad. Jézio H. Bonfim Gutierre. Bauru: EDUSC, 1999.

PULGARÍN CUADRADO, Amália. Metaficción historiográfica: la novela histórica en la narrativa hispánica postmodernista. Madrid: Editorial Fundamentos, 1995.

QUIJANO, Aníbal. Colonialidade do poder, eurocentrismo e América Latina. In: . A colonialidade do saber: eurocentrismo e ciências sociais. Perspectivas latino-americanas. Buenos Aires: Clacso Livros, 2005.

ROCHA, Hélio Rodrigues de. Microfísicas do imperialismo. A Amazônia rondoniense e acreana em quatro relatos de viagem. Curitiba: CRV, 2012. 